\title{
Framework for Structuring Public Private Partnerships in Railways
}

\author{
Rachna Gangwar \\ G Raghuram
}

W.P. No. 2013-09-04

September 2013

The main objective of the working paper series of the IIMA is to help faculty members, research staff and doctoral students to speedily share their research findings with professional colleagues and test their research findings at the pre-publication stage. IIMA is committed to maintain academic freedom. The opinion(s), view(s) and conclusion(s) expressed in the working paper are those of the authors and not that of IIMA.

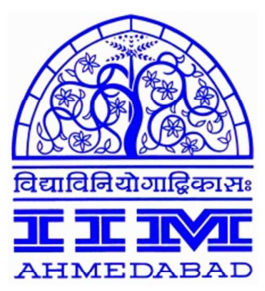




\title{
Framework for Structuring Public Private Partnerships in Railways
}

\author{
Rachna Gangwar (rachna015@gmail.com) \\ Institute of Management Technology, Ghaziabad \\ G Raghuram (graghu@iimahd.ernet.in) \\ Indian Institute of Management, Ahmedabad
}

\begin{abstract}
Structuring Public Private Partnerships (PPPs) in railways is a challenge, given its technology base, and obligation as a public and affordable mode of transportation. The sector provides strong incentives for vertical integration due to economies of scope. However, it is evident from the literature that large integrated PPPs in railways systems are not feasible due to higher commercial risks. They also suffer from implicit cross subsidization since the railway infrastructure is capital intensive, common to multiple revenue sources, and fare box revenues are generally not sufficient to recover investments. This is being addressed by various unbundling approaches in recent PPPs.
\end{abstract}

This research explores the potential of unbundling the railway system into over 40 'elements' wherein an element is the smallest unit that can be given to a party for execution. This would however result in significant horizontal and vertical interfaces between these elements.

A sustainable PPP would need to limit the extent of interfaces due to transaction costs and risks. This can be achieved by bundling the elements horizontally and/or vertically into 'entities' to extract the best value for a PPP. The governing principles would be scale economies (horizontal integration), scope economies (vertical integration), need for competition (horizontal disaggregation), level playing field, transactional transparency, and need for specialization (vertical disaggregation). Additional drivers would be appetite for investment, availability of competence and accountability for an entity. The findings of the research indicate that the entity formation is one of the most crucial aspects of a PPP in railways.

A consequential critical area is managing the interfaces between entities, which are subject to transaction costs and risks. These should be carefully identified and addressed by welldesigned contractual agreements and independent regulation.

Keywords: Public Private Partnerships, Railway Infrastructure, Unbundling, Vertical Integration 


\section{INTRODUCTION}

Development of railways only with public resources is a challenge for many governments across the world. Public Private Partnerships (PPPs) have emerged as a way forward for additional resources and increased market orientation. However, these are complex arrangements and can create potential problems if not properly structured and administered.

PPPs in railways are more challenging to structure than other modes due to railway's specific technology base, obligation as a public and affordable mode of transportation, and strong incentives for economy of scope. Typical policy questions include (i) which elements could be given to private sector, (ii) whether to one party or several parties (iii) how to make a project financially viable if fare box revenues are not sufficient, and (iv) what additional regulatory measures will be required to protect the interests of various stakeholders (government, private parties and users) etc.

\section{BACKGROUND OF PPPS IN RAILWAYS}

\section{What is a PPP?}

The term "Public-Private Partnership" (PPP or P3) has been in general use since 1990's, yet there is no widely agreed single definition or model of a PPP (Bernardino, 2010; OECD, 2010; The World Bank, 2006). Broadly it is a long term partnership between public and private sector for provisioning of public assets/services with substantial risk shared by the private party. Variations exist in different countries according to their earlier practices in the split of responsibilities between the State and private companies regarding provision of services of public interest (Viegas, 2010).

For the purpose of this research, we adopt the umbrella definition suggested by the Department of Economics Affairs (DEA) India which states that "PPP is an arrangement between a government or statutory entity or government owned entity on one side and a private sector entity on the other, for the provision of public assets and/or related services for public benefit, through investments being made by and/or management undertaken by the private sector entity for a specified time period, where there is a substantial risk sharing with the private sector and the private sector receives performance linked payments that conform (or are benchmarked) to specified, pre-determined and measurable performance standards (DEA, 2010)."

\section{Types of PPPs in Railways}

Private investment in railways is not a new phenomenon. In fact, railways were originally built and operated by private companies in most parts of the world. However, with time, it became clear that network economies and reduced scope for competition put railways in a 
situation where a pure market was not the most beneficial system, and States began to take over their construction and operation (Bernardino, 2010).

Since the late 90 s, governments started increasingly relying on private sector for financing of railway infrastructure or providing various services. Regulatory frameworks were created to guarantee the performance of private sector and protect the interests of users. What distinguishes the current partnerships from the earlier is the way they are perceived and managed, and the role of regulation.

The recent move to attract private sector participation was driven by railways loosing competitiveness to road and air. These two sectors have witnessed huge investments in the past few decades. The reasons for railways' deteriorating market share were inadequate investment in infrastructure, poor services, lack of marker orientation, and overstaffing in railway companies. To address these problems, some governments restructured their public railway organizations into private companies/corporations. Some others opted for organizational and/or regulatory reforms to create a better policy environment for private participation.

It can be seen from various reforms that private participation in railways can be of two types: infrastructure related or service related. Infrastructure related implies that the private party invests in creating and maintaining the infrastructure for the concession period. Service related implies that private party provides transport services with or without owning the rolling stock. Private participation in services yielded good results in the UK and many other countries but in infrastructure, it is still a challenge (Nash, 2002).

Should the scope of PPPs in railways limit to only infrastructure or should it also include services is contestable. In the European Union where services were opened to competition after the 1991 EC Directive (EC, 1991), private participation in services is not viewed as PPPs. This is also true in India for other transport sectors where services are open to competition eg, aviation and maritime. However, since railways in India and many other parts of the world are still integrated, we include services under the ambit of PPPs in our framework.

\section{PPP Models}

There are different models of PPP contracts depending on the split of responsibilities between public and private parties (Hansen, 2010). These models comprise some combination of design build, finance, maintain, operate and transfer components (Higton and Clark 2010).

PPP models in railways are still emerging due to complexities involved. Road models can not be directly applied for railways since rail sector differs significantly from road in terms of technical expertise and level of capital investment.

Hansen (2010) studied 15 PPP projects. Of these, eight have been awarded and seven are in the pipeline. Table 1 gives the list of these projects. 
Table 1: Railway PPP Projects

\begin{tabular}{|c|c|c|c|c|c|c|}
\hline & $\begin{array}{l}\text { Design \& } \\
\text { Construction } \\
\text { period }\end{array}$ & $\begin{array}{l}\text { Conces- } \\
\text { sion } \\
\text { period } \\
\text { [years] }\end{array}$ & $\begin{array}{l}\text { Route } \\
\text { length } \\
{[\mathrm{km}]}\end{array}$ & $\begin{array}{l}\text { Invest- } \\
\text { ment } \\
\text { costs }\end{array}$ & Public funds & Contract \\
\hline $\begin{array}{l}\text { Channel tunnel } \\
\text { rail link CTRL }\end{array}$ & $\begin{array}{l}1996- \\
2003 / 2007\end{array}$ & 90 & 109 & $£ 5.8 \mathrm{bn}$ & $£ 2,010 \mathrm{~m}$ & DBFM \\
\hline $\begin{array}{l}\text { Öresund road-rail } \\
\text { link }\end{array}$ & 1991-2000 & $25-30$ & 38 & $€ 2$ bn & $\begin{array}{l}100 \% \text { state } \\
\text { guarantee }\end{array}$ & DBFM \\
\hline $\begin{array}{l}\text { HSL-Zuid } \\
\text { Amsterdam-Belg. }\end{array}$ & 2000-2007 & 25 & 100 & $€ 6$ bn & $\begin{array}{l}€ 110 \mathrm{~m} \\
\text { /year }\end{array}$ & DBFM \\
\hline $\begin{array}{l}\text { Alice Springs- } \\
\text { Darwin rail }\end{array}$ & 2000-2004 & & & A\$1.2bn & AS559 m & DBOFM \\
\hline $\begin{array}{l}\text { Taipei-Kaohsiung } \\
\text { HS rail }\end{array}$ & 2000-2007 & 35 & 335 & US\$18bn & & DBOFM \\
\hline $\begin{array}{l}\text { Perpignan- } \\
\text { Figueras HS rail }\end{array}$ & 2005-2009 & 50 & 45 & $€ 1.1 b n$ & $\begin{array}{l}€ 540 \mathrm{~m} \\
+62 \mathrm{~m}\end{array}$ & DBFM \\
\hline $\begin{array}{l}\text { Diabolo rail link } \\
\text { Brussels }\end{array}$ & 2007-2012 & 35 & 3 & $€ 540 \mathrm{~m}$ & $\begin{array}{l}€ 250 \mathrm{~m} \\
\text { track\&sig. }\end{array}$ & $\mathrm{DBF}$ \\
\hline $\begin{array}{l}\text { Liefkenshoek } \\
\text { raillink Antwerp }\end{array}$ & 2008-2013 & 38 & 16 & $€ 840 \mathrm{~m}$ & $€ 50 \mathrm{~m} /$ year & DBFM \\
\hline Tours-Bordeaux & 2010-2016 & 44 & 340 & $€ 7.2 \mathrm{bn}$ & $\leq \mathbf{5 0} \%$ & DBFM \\
\hline $\begin{array}{l}\text { HS rail } \\
\text { GSM-R network } \\
\text { France }\end{array}$ & 2009-2015 & 15 & 14000 & $€ l$ bn & $€ 160 \mathrm{~m}$ & DBOFM \\
\hline $\begin{array}{l}\text { Lisbon-Madrid } \\
\text { HS rail }\end{array}$ & 2009-2013 & 40 & $>165$ & $€ 7.8 \mathrm{bn}$ & & DBFM \\
\hline $\begin{array}{l}\text { Nimes-Montpell. } \\
\text { HS rail }\end{array}$ & 2011-2016 & & 80 & $€ 1.62 \mathrm{bn}$ & & DBFM \\
\hline $\begin{array}{l}\text { Brittany-Pays de } \\
\text { la Loire HS rail }\end{array}$ & 2011- & & 182 & $€ 2.85 \mathrm{bn}$ & & DBFM \\
\hline $\begin{array}{l}\text { Rio de Jan-Sao P- } \\
\text { Campinas HS rail }\end{array}$ & 2011-2017 & 40 & & $\$ 18.7 \mathrm{bn}$ & & DBOF \\
\hline $\begin{array}{l}\text { Kolkkola- } \\
\text { Ylivieska rail link }\end{array}$ & 2011-2014 & $20-30$ & $\begin{array}{l}76 \\
2^{\text {nd }} \text { track }\end{array}$ & $€ 660 \mathrm{~m}$ & & DBFM \\
\hline
\end{tabular}

Source: Hansen, 2010

It can be observed from this list that almost all projects required government subsidies, at times more than $50 \%$ of the project cost. This implies that fare box revenues are not always sufficient to recover investments in infrastructure. This has to be dealt appropriately in PPP structuring. Policy decisions could be to provide direct subsidy, award on annuity, or bundle the project with positive externalities such as land development. 
In terms of project structuring, most of these projects are awarded on design, build, finance and maintain (DBFM) basis. Unlike other sectors, operation of trains is not bundled in most of the concessions. Hansen (2010) argues that unbundling of infrastructure and train operations can reduce overall costs and risks by stimulating increased competition and higher contract flexibility. Dehornoy (2012), based on his analysis of 27 rail PPP projects, has reported that railway PPPs are moving from integrated concession towards asset only concessions. Additionally, asset only PPPs are moving from traffic based concessions towards availability based concessions ${ }^{1}$ since transferring traffic risks to private sector had proved costly in most cases eg Channel Tunnel Rail Link, Eurotunnel, Taiwan High Speed Railway etc.

\section{FRAMEWORK FOR PPPS}

It can be seen from the literature that PPPs in railways can take many forms based on the project size, scope, cost, risks profile, life cycle of the infrastructure, expertise available in the market, and public sector policies etc. The earlier PPPs were all integrated. In the recent years, the asset-only PPPs have gained importance with an emphasis on high availability of assets. More recently, the researchers are moving towards further disaggregation based on the specialization requirements and consequent availability of competence.

\section{Elements of a Railway System}

First, we identify all elements that form a railway system.

We adopt and build on the structure given by Pangotra and Raghuram (1999) that classifies any transport system into three broad segments: infrastructure, services and regulation. Infrastructures are categorized into right of way, terminals and rolling stock. Services are categorized into maintenance, operations and customer services. Areas for regulation are licensing, environmental impact, safety and security, pricing, service levels, and dispute resolution (Raghuram, 2001). This framework can be graphically represented as shown below:

Table 2: Classification of Transport System

\begin{tabular}{|c|c|c|c|c|c|}
\hline & \multirow{2}{*}{$\begin{array}{l}\text { Infrastructure } \\
\text { Ownership and } \\
\text { Asset Creation }\end{array}$} & \multicolumn{3}{|c|}{ Services } & Regulation \\
\hline & & Maintenance & Operations & $\begin{array}{l}\text { Customer } \\
\text { Services }\end{array}$ & \multirow{4}{*}{$\begin{array}{l}\text { 1. Licensing } \\
\text { 2. Environmental impact } \\
\text { 3. Safety and security } \\
\text { 4. Pricing } \\
\text { 5. Service levels } \\
\text { 6. Dispute resolution }\end{array}$} \\
\hline $\begin{array}{l}\text { Right of } \\
\text { way }\end{array}$ & & & & \multirow{3}{*}{$\begin{array}{l}\text { Basic } \\
\text { Services } \\
\text { Value Added } \\
\text { Services }\end{array}$} & \\
\hline Terminals & & & & & \\
\hline $\begin{array}{l}\text { Rolling } \\
\text { stock }\end{array}$ & & & & & \\
\hline
\end{tabular}

Source: Raghuram, 2001

\footnotetext{
${ }^{1}$ In traffic based concessions, the concessionaire receives commercial revenue. In availability based concessions, the public authority retains the commercial risk and makes payments to the concessionaire based on performance indicators.
} 
We now build this up for the railway sector by analysing each infrastructure segment separately. We start with identifying various assets that need to be created for delivery of that infrastructure. We then identify various service components pertaining to maintenance, operations and customers for that particular infrastructure segment. We illustrate this for 'right of way' infrastructure segment.

Right of way infrastructure for railways would include substructure (civil works), superstructure, bridges/tunnels, overhead electrification, telecommunication network, signalling system etc. In addition, there would be some ancillary facilities such as train formation yards and storage sidings.

Maintenance services for right of way would include regular maintenance (cleaning of tracks, garbage collections etc), repairs, preventive measures, and regular inspections. Similarly, operations would include scheduling and control of trains, safety measures, and emergency control measures. Right of way may not have any direct customer interface. However, it can be used for value added telecom services and its airspace can be used for advertisements.

Similarly, we identify various assets and services components for terminals and rolling stock.

Additional areas that would need regulation in railways, especially in the context of PPPs, are anti discrimination and standardization. Table 3 provides an elaborate list of elements identified for the railway sector.

All these elements, when put together, form a railway system. Traditionally, all these elements were created and managed by the public sector through a vertically integrated railway organization. In the context of a PPP, a careful analysis is needed as to what elements from this system could be given to the private sector so that the intended objectives of the project can be achieved while retaining the interests of public and private sectors.

We evolve in next sections a framework and some principles for appropriate bundling of various elements for a PPP project design. 
Table 3: Elements of a Railway System

\begin{tabular}{|c|c|c|c|c|c|}
\hline & \multirow{2}{*}{$\begin{array}{l}\text { Ownership and Asset } \\
\text { Creation }\end{array}$} & \multicolumn{3}{|c|}{ Services } & \multirow{2}{*}{ Regulation } \\
\hline & & Maintenance & Operations & $\begin{array}{l}\text { Customer } \\
\text { Services }\end{array}$ & \\
\hline $\begin{array}{l}\text { Right of Way } \\
\text { Infrastructure } \\
\circ \text { Sub soil and track substructure } \\
\circ \text { Track superstructure } \\
\circ \text { Bridges/tunnels } \\
\circ \text { Signalling } \\
\circ \text { Telecommunication } \\
\circ \text { Power supply } \\
\text { Ancillary facilities } \\
\circ \quad \text { Train formation yards } \\
\circ \quad \text { Storage sidings }\end{array}$ & $\begin{array}{l}\text { Provisioning and } \\
\text { ownership of right of } \\
\text { way }\end{array}$ & $\begin{array}{ll}\circ & \text { Cleaning } \\
\circ & \text { Regular inspections } \\
\circ & \text { Repairs } \\
\circ & \text { Preventive } \\
& \text { maintenance }\end{array}$ & $\begin{array}{ll}\circ \text { Scheduling and train } \\
\text { control } \\
\circ \text { Safety } \\
\circ \text { Emergency control }\end{array}$ & $\begin{array}{l}\text { Air space } \\
\text { (advertisement, } \\
\text { telecom) }\end{array}$ & \multirow{3}{*}{$\begin{array}{l}\text { 1. Licensing } \\
\text { 2. Environmental impact } \\
\text { 3. Safety and security } \\
\text { 4. Pricing } \\
\text { 5. Service levels } \\
\text { 6. Dispute resolution } \\
\text { 7. Anti discrimination } \\
\text { 8. Standardization }\end{array}$} \\
\hline $\begin{array}{l}\text { Terminals } \\
\circ \text { Stations } \\
\circ \text { Goods Terminals }\end{array}$ & $\begin{array}{l}\text { Provisioning and } \\
\text { ownership of terminals }\end{array}$ & $\begin{array}{ll}\circ & \text { Cleaning } \\
\circ & \text { Regular } \\
\text { maintenance }\end{array}$ & $\begin{array}{ll}\circ & \text { Station management } \\
\circ & \text { Fare collection }\end{array}$ & Ticketing & \\
\hline $\begin{array}{l}\text { Rolling Stock } \\
\circ \text { Locomotives } \\
\circ \text { Wagons } \\
\circ \text { Coaches }\end{array}$ & $\begin{array}{l}\text { Provisioning and } \\
\text { ownership of rolling } \\
\text { stock }\end{array}$ & $\circ$ Regular inspections & $\begin{array}{ll}\circ & \text { Passenger services } \\
\circ & \text { Freight services }\end{array}$ & On board services & \\
\hline
\end{tabular}


We build our framework around broad functions identified in various railway restructuring processes and earlier railway PPP projects, which are infrastructure, operations and services (Figure 1). Here, by infrastructure we mean infrastructure provisioning, by operations we mean network operations and by services we mean transport services.

Figure 1: Functions of Railways

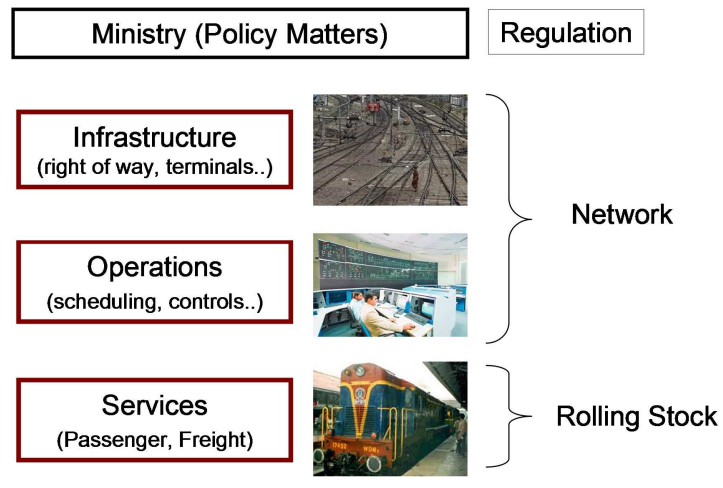

Source: Authors

To build this up further for disaggregated analysis, all identified infrastructural elements and related services (table 3 ) are allocated across the three functions mentioned above. While allocating elements within a function, interfaces that provide scope for disaggregation are recognized. For example, infrastructure maintenance is possible to outsource to an external party. Similarly, party providing transport services need not necessarily own and maintain the rolling stock. These activities can also be provided by third parties.

To cover all activities and stakeholders, we further include land acquisition and clearances (environmental etc) which are integral to PPPs, and authorities responsible for policy making (the ministry) and licensing, and end customers to the framework. Figure 2 gives the evolved framework.

Here, the disaggregation into elements has been done primarily for 'right of way' components including infrastructure creation, maintenance, and operations. However, only the core elements are included. Going more into detail, there might be many ancillary facilities that might be included. These would include electrical supply equipment for traction, refuelling facilities, marshalling yards, train formation facilities, storage sidings, maintenance and other technical facilities etc. For the purpose of this framework, these facilities will not have significant impact since these would come under the purview of the player providing superstructure facilities.

Similarly, terminals could have core infrastructure and non-core infrastructure, which could be further disaggregated into elements. 
Figure 2: Unbundled Railway System

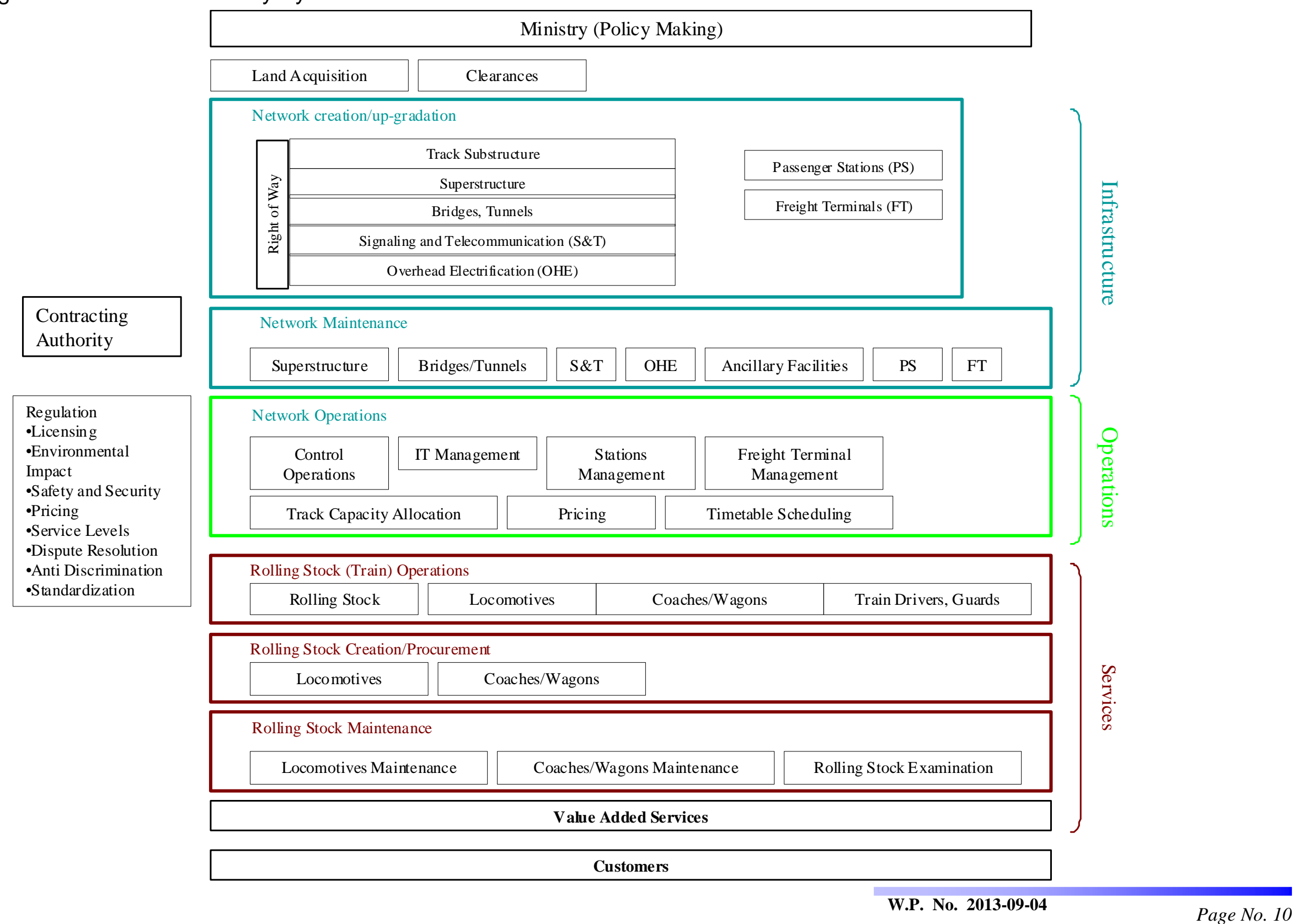


The above framework has more than 40 elements, which have been disaggregated vertically and horizontally. For a given project, the vertical and horizontal disintegration represents various functionalities. In the case of a large project that needs to be split into several smaller projects, the horizontal disaggregation could represent various geographies and/or market segments and/or different organizations addressing the same market.

Each element in the framework creates a vertical and/or horizontal interface, which would be subject to transaction costs and risks. Each vertical and horizontal interface should be analyzed for risks (coordination, technology, service levels, conflicts of interest etc) and opportunities (ability to leverage competition, specialized competence etc).

\section{Entity Formation}

While theoretically each element of the framework can be undertaken separately, this will not be feasible due to huge transaction costs and risks that would be incurred from various interfaces. This would require bundling of elements into 'entities.' An entity can be defined as a set of elements that could be bundled together horizontally and/or vertically to extract the best value in a PPP project. This bundling would be project specific based on the commercial viability, risk profile, and need for specialization etc. When it is undertaken by a private party, it would be referred as the 'private entity' in this research. A PPP project can have one or more private entities depending on the financial, technical, and specialization requirements. The remaining elements of the system would be provided by the public sector, which would be referred as 'public entities' in this research. Any PPP project would consists of at least one private and one public entity. The interfaces between the entities would be managed by the contractual agreements.

\section{Principles for Bundling}

The framework given in Figure 2 provides an important perspective for analyzing various structuring options that can be built by appropriate bundling of elements horizontally and/or vertically into an entity. As discussed earlier, the railway sector provides strong incentives for vertical and horizontal bundling. However, a sustainable2 framework for PPPs would limit the extent of horizontal and vertical bundling of elements since considerations like appetite for the extent of business, need for competition, level playing field and transactional transparency, ability to transfer revenue and technology risks, life cycle of the product etc would be important. Commercial viability of the 'entity' would be important for attracting the private sector.

For a sustainable PPP, the formation of entity should be driven by the principles of scope economies, scale economies, competition, and level playing field/transactional transparency/need for specialization. For a vertically disintegrated railway system (Figures 1 and 2), the vertical bundling of functions/elements would leverage scope economies but at the same time it would have implication on level playing field. The vertical unbundling would

\footnotetext{
${ }^{2}$ Sustainable PPP in this research implies that the project is commercially viable for the private sector and contributes in the economic development of the society.
} 
improve level playing field, transactional transparency and provide for specialization requirements but it will pose additional transactions costs and therefore would result in loss of scope economies. Similarly, the horizontal bundling would leverage scale economy but would reduce the scope for competition. Appropriate bundling/unbundling of elements for each project would depend on the project objective and other requirements. Additional drivers that would drive the entity formation are accountability and synergy between elements.

Scope Economy: The vertical integration of functions/elements would leverage scope economies. The driver for scope economy is the reduction in transaction costs across vertically related elements. Examples would be integration between infrastructure and services such as airports and airlines, ports and shipping lines, power generation and distribution etc.

Scale Economy: The horizontal integration of elements would leverage scale economies. The driver for scale economy is the reduction in cost per unit as the size of the activity increases, due to associated fixed costs. Examples would be the container terminals at ports, shipping lines, rail wagon manufacturing units etc. Per unit costs would reduce as the size of the activity increases.

Competition: Need for competition would require horizontal unbundling, which could represent different geographies and/or market segmentation (even in the same geography) and/or different organizations addressing the same market. The drivers for competition are efficiency, choices for end customers, and improved service levels. Examples of geographical disaggregation could be separation of Japanese railway network into regions, state-wise licenses to electric power distributors, telecom operators in India etc, while the examples of market segmentation could be freight, passenger, regional and urban transport. Examples of organizations addressing the same market would be licensing of multiple container train operators, telecom service providers, shipping lines, airlines etc.

Level Playing Field: Need for level playing field/specialization/transactional transparency/life cycle of the product would require vertical disaggregation. Examples would be separation between terminals and service lines, as in the case of telecom, air, and water sector. Lack of such separation in the container train operations business has created problems due to the consequent lack of level playing field, especially in the context of a large incumbent.

The application of bundling/unbundling principles has been demonstrated in figures 3 and figure 4. Three mutually exclusive lines, which could be separated either by geography and/or market segments have been considered in Figure 3. Example of geographically separated lines could be Ahmedabad-Vadodara, Vadodara-Surat and Surat-Mumbai. Example of separation by market segment could be long distance and regional passenger services on Ahmedabad-Mumbai route. At a macro level wherein a line can be unbundled into infrastructure, operations, and services, the horizontal integration of lines/services would enable scale economy, and the vertical integration of functions would enable scope economy in the project. On the other hand, the horizontal separation would leverage competition and the vertical separation would improve the level playing field/ transactional 
transparency/scope for specialization. The appropriate bundling for each project would be specific to the project requirement.

Figure 3: Bundling at Macro Level

Level Playing Field/ Need for specialization/ Transactional Transparency

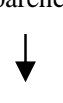

Mutually Exclusive Lines based on market segments and/or geography

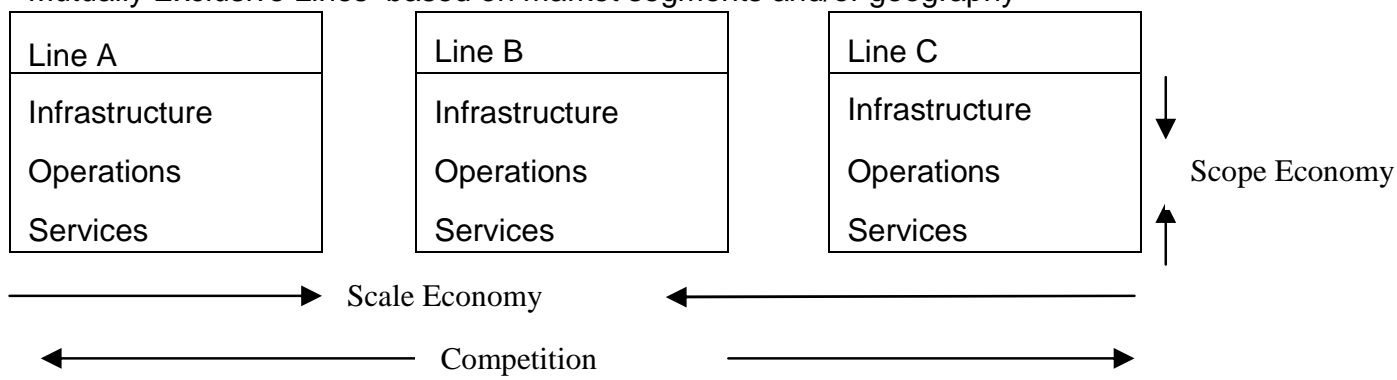

The bundling principles would apply even if a railway project is unbundled further into elements. For example, two geographically separated lines on asset only basis can be further unbundled into substructure, superstructure, bridges, tunnels, signaling, overhead electrification, telecommunication, and terminals (Figure 4). Example could be lines between Ahmedabad-Surat and Surat-Mumbai. The application of bundling principles for horizontal/vertical integration/separation would be the same as in the previous example.

Figure 4: Bundling at Micro Level

Level Playing Field/ Need for specialization/ Transactional Transparency

$$
\downarrow
$$
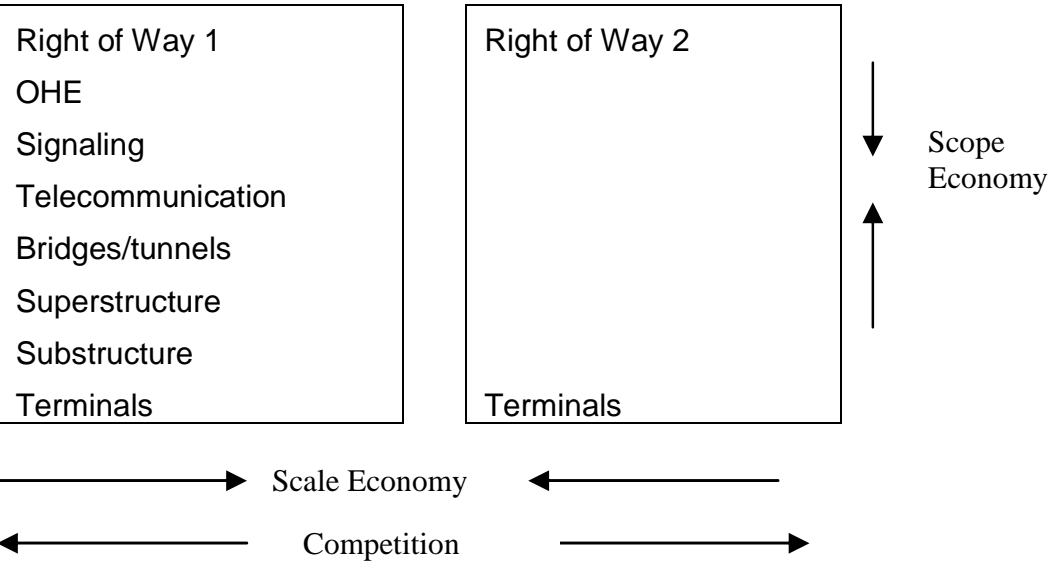

Figure 5: Example of a Possible Entity

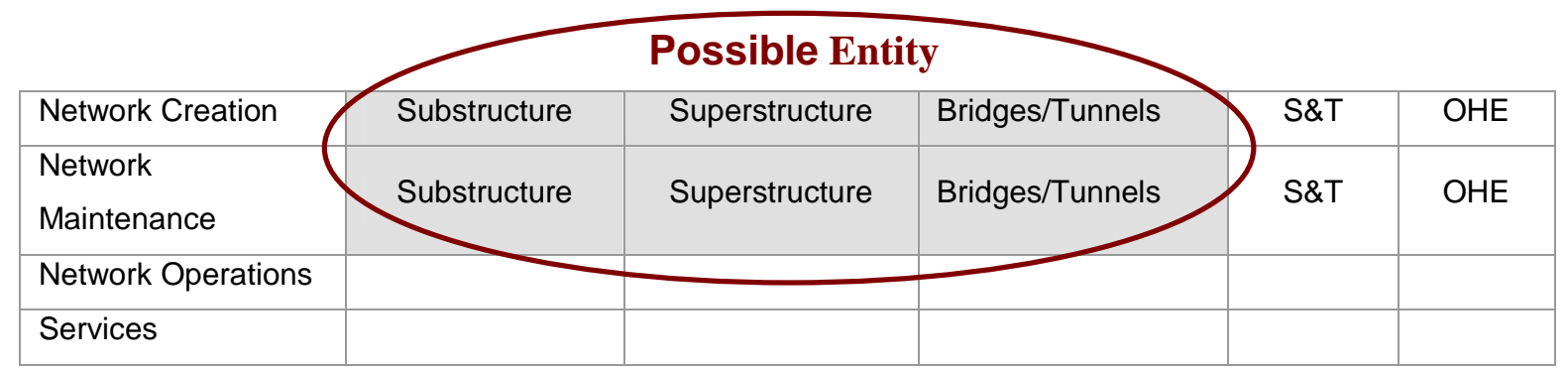


While there are various possibilities, the entity formation needs careful analysis. The entities may suffer from lack of competition, level playing field, accountability, conflicts of interest etc. The governance of entity (proximity with public authority, cross ownership etc) is also important to avoid conflict of interest.

\section{Interfaces between Entities}

The interfaces would be subject to many risks including construction quality, maintenance, service levels, tariffs, coordination, technology etc, which would be managed by the contractual agreements. These agreements would list all terms and conditions that the entities would be legally bound to. The nature and content of these agreements would depend on the project type (asset-only, service PPP, or integrated), number of entities, scope of each entity, type of interface between entities (possible conflicts of interest etc), and the number of public administrations involved (central and/or state and/or local government etc). Typical PPP contracts include concession agreement, operations and maintenance agreement, land lease agreement, state support agreement etc. Most agreements have an upstream entity (contracting authority) and a downstream entity (concessionaire). Welldesigned and well-written agreements between entities would minimize the interface risks and scope for interpretation, which has been a problem in most of the PPPs in India.

A number of problems in current PPPs in India can be attributed to failure in identifying and managing interfaces between entities. Issues that have emerged from poor management of interfaces include lack of accountability, non-compliance with agreements, abuse of monopoly position, one sided dispute resolution mechanisms, lack of independent regulation etc. To take the example of Delhi Airport Metro Express (DAME), the concession agreement failed to recognize the vertical interface between DMRC (contracting authority) and Reliance (concessionaire) which resulted in blame game between both parties and finally closing of the line for more than six months. The project also failed to mitigate the horizontal interface risk between DMRC and the DAME, which resulted in making DAME a stand-alone line with poor integration with the remaining network and thus low ridership.

PPP projects very often suffer from conflicts of interest, especially when the public entity is also providing the similar elements as the private entity or has proximity to the contracting authority. Examples are container terminals at the JNPT port, container train operators etc. Independent regulation is must to protect the interests of all entities and the end users.

While the entity formation and management of interfaces are the key component of a PPP, there might be other elements such as hotels, restaurants etc that could also be part of the project. These are value added services, for which the users of the transport system would be the primary customers. While the development of these services would be important for the core project, bundling of these elements with core project could create conflicts of interest since non-core services provide better returns compared to core services. 


\section{CONCLUSIONS}

Entity formation is one of the most crucial aspects of a PPP since it determines the scope of work for the private party. Entity formation should be driven by the principles of scope economies (vertical integration), level playing field/transactional transparency/need for specialization (vertical disaggregation), scale economies (horizontal integration), and competition (horizontal disaggregation). Addition drivers would be accountability and synergies between interfaces. An example of accountability would be bundling of network creation and network maintenance.

The extent of horizontal and vertical integration in a project should be determined by the appetite of the private sector, specialization requirements, consequent availability of competence, and need for competition. The entity formation should demonstrate a clear assessment of these and minimize any obligatory conditions which has been the case of some of the Indian PPPs such as PRCL.

A consequential critical area is managing the interfaces between entities, which are subject to various risks. Interfaces must be carefully identified and addressed by well-designed contractual agreements and independent regulation. In addition to vertical interfaces, horizontal interfaces need to be identified and addressed. Horizontal interfaces between entities, resulting from geographic separation or appetite of the developer, pose coordination and performance risks that could be addressed by performance guarantees and appropriate regulatory measures.

\section{REFERENCES}

Bernardino, João, Zden_ek H_rebí_cek and Carlos Marques (2010). "Applying social marginal cost pricing in rail PPPs: Present state, drawbacks and ways forward," Research in Transportation Economics 30 (2010) 59-73

DEA (2010). "Approach Paper on Defining Public Private Partnerships, Discussion Note," February 2010, Department of Economic Affairs, Ministry of Finance, Government of India

Dehornoy, Julien (2012). "PPPs in the rail sector - A review of 27 projects," MPRA Paper No. 38415, Munich Personal RePEc Archive, Retrieved from http://mpra.ub.unimuenchen.de/38415/

EC (1991). Council Directive 91/440/EEC of 29th July 1991 on the Development of the Community's Railways, The Council of the European Communities

EC (2004), Resource Book on PPP Case Studies, Retrieved from http://ec.europa.eu/regional_policy/sources/docgener/guides/pppresourcebook.pdf

Fernandes, Carlos (2010). "Developing High Speed Rail Projects: Defining the Business Model," Presentation at the International Practicum on Implementing High Speed Rail in the United States. Retrieved from 
http://www.apta.com/mc/hsr/previous/2010/HighSpeed\%20Rail\%20Presentations/De veloping-High-Speed-Rail-Projects.pdf

Hansen, Ingo A (2010). "Review of Public Private Partnerships in Heavy Rail Infrastructure Projects," European Cooperation in Science and Technology COST Action P3T3, Lisbon, January 12, 2011

Higton N and Steven L. Clark (2010). "Using PPPs to deliver Successful Rail Projects," ASME Conference Proceedings, Joint Rail Conference, Volume 2, Planning, Management and Operation

Nash, Chris and Bryan Matthews (2002). "Implementing rail infrastructure charging reform barriers and possible means of overcoming them," Imprint-Europe

OECD (2010). "Dedicated Public Private Partnership Units: A survey of Institutional and Governance Structures," Organization for Economic Co-operation and Development.

Pangotra, Prem and G Raghuram (1999). "Resource Mobilisation Strategies for Financing of Transport Infrastructure and Services," Infrastructure Development and Financing: Public Private Partnership, Macmillan India Ltd, New Delhi, 1999

PPAIF (2006). "Hybrid PPPs: Levering EU funds and private capital." Retrieved from http://www.ppiaf.org/sites/ppiaf.org/files/publication/WB\%20Hybrid\%20PPPs\%20$\% 202006 . p d f$

Priemus, Hugo (2009). Contracting Public Transport Infrastructure: Recent experience with the Dutch High Speed Line and the Amsterdam North-South Metro Line, Paper presented at the 11th International Thredbo Conference on Competition and Ownership in Land Passenger Transport, Delft University of Technology, September 21, 2009

Raghuram, G (2001). "The Transport Sector," India Infrastructure Report," 3iNetwork, Oxford University Press, 2001

Railway Gazette (2011). "Perpignan - Figueres link inaugurated," Retrieved from http://www.railwaygazette.com/en/news/personnel/single-view/view/perpignanfigueres-link-inaugurated.html

Rutzen, Beatriz and C. Michael Walton (2011). High Speed Rail: A Study of International Best Practices and Identification of Opportunities in the U.S., Research Report SWUTC/11/476660-00071-1, Center for Transportation Research, University of Texas at Austin

Silva, João de Abreu e, Duarte Silva and Joseph Sussman (2011). "The Portuguese High Speed Rail Network; Relating Financing to Strategic and Operating Issues," Massachusetts Institute of Technology, Engineering Systems Divison, ESD-WP2011-02, esd.mit.edu/wps

The World Bank (2006). "India: Building Capacities for Public Private Partnerships," Energy and Infrastructure Unit and Finance and Private Sector Development Unit South Asia Region, June 2006

Viegas, José M. (2010). "Questioning the need for full amortization in PPP contracts for transport Infrastructure," Research in Transportation Economics 30 (2010) 139-144

Vieillescazes, Thomas, (2007). The French PPP Experience in the Rail Sector, Presentation in Regional PPP Workshop, Riga, March 6-8, 2007

Wilden, Paul Van der (2004). Holland's Landmark PPP High Speed Rail Project, Euromoney Magazine Annual PPP Yearbook, June 2004 